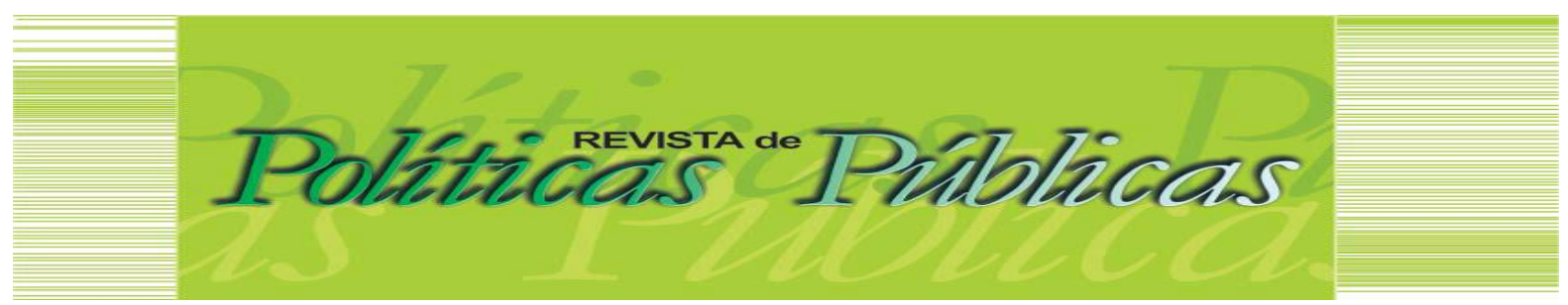

\title{
LEGISLATIVE POLICIES AND CULTURE ON PARENTING PRACTICES: improving the parent-child relationship in South Africa
}

\author{
Edna G. Rich ${ }^{1}$ \\ Nicolette V. Roman ${ }^{2}$
}

\begin{abstract}
Resumo
Os relacionamentos pai-filho são frequentemente descritos como vínculos únicos e duradouros que ocorrem entre um cuidador / pai e seu filho. Vários documentos de políticas legislativas sul-africanas foram implementados para orientar a prestação de serviços às famílias e fortalecer o relacionamento entre pais e filhos nas famílias. Este artigo visa examinar criticamente os quadros atuais e explorar o que é necessário na África do Sul, a fim de melhorar o relacionamento entre pais e filhos e os resultados gerais do desenvolvimento infantil. Utilizando uma perspectiva ecológica, os aspectos identificados como benéficos para melhorar o relacionamento entre pais e filhos na África do Sul são discutidos em nível micro, meso e macro. As influências culturais são consideradas e são fornecidas recomendações para melhorar o relacionamento entre pais e filhos em um contexto sul-africano.

Palavras-chave: Relacionamento pai-filho. Desenvolvimento infantil. Desenvolvimento na primeira infância. Estilos parentais. Cultura. Teoria dos sistemas ecológicos.
\end{abstract}

POLITICAS LEGISLATIVAS E CULTURA PRÁTICAS PARENTAIS: melhorando o relacionamento entre pais e filhos na África do Sul

\begin{abstract}
:
Parent-child relationships are often described as unique and enduring bonds that take place between a caregiver/parent and their child. Several South African legislative policy documents have been implemented to guide service delivery to families and to strengthen the parent-child relationship in families. This paper aims to critically examine the current frameworks and explore what is required in South Africa in order to improve the parent-child relationship and overall child developmental outcomes. Utilising an ecological perspective, aspects identified as beneficial towards improving the parent-child relationship in South Africa are discussed on a micro-, meso- and macro-level. Cultural influences are considered, and recommendations are provided in order to improve the parent-child relationship in a South African context.
\end{abstract}

Keywords: Parent-child relationship. Child development. Early childhood development. Parenting styles. Culture. Ecological systems theory.

Artigo recebido em: 29/08/2018 Aprovado em: 28/03/2019. DOI: http://dx.doi.org/10.18764/2178-2865.v23n1p389-401

\footnotetext{
${ }_{1} \mathrm{PhD}$ in Social Work at the University of the Western Cape (UWC). She is a lecturer in the interdisciplinary Child and Family Studies Unit currently located in the Social Work department at UWC. Her areas of research interests are: parenting research, child and youth development; family functioning; family well-being; and the factors that put children, families and communities at risk, such as substance abuse in the family. Child and Family Studies Unit, Faculty of Community and Health Sciences, University of the Western Cape, Cape Town, South Africa. E-mail: erich@uwc.ac.za

$2 \mathrm{PhD}$ in Psychology. She is the DST/NRF/NDP SARChl Chair in Human Capabilities, Social Cohesion and the Family, rated as an Established Researcher nationally and a Professor in child, youth and family science at the University of the Western Cape. Her research focuses on the parent-child relationship to strengthen families across the lifespan. Awards she has achieved include the Chancellor's Outstanding Alumni Award in Health Sciences, the Dean's Research Excellence Merit Award in the Faculty of Community and Health Sciences and the Academic Achievers Award: Established Researcher Award in the Faculty of Community and Health Sciences. E-mail: nroman@uwc.ac.za
} 


\section{INTRODUCTION}

Many theorists such as Sigmund Freud (1856-1939) believe that adult development is greatly defined and dependent on the relationships that children share with their parents. Parenting and caregiving refer to the process of being, sensitive, loving, nurturing and responsive to the child. It is crucial that caregivers promote child development through secure parenting. Recently Rubin and Chung (2013), found that when and how a parent cares for a child is often influenced by culture and the extent to which the parent permits the child's freedom to explore, how nurturing or restrictive the parent is and which behaviours the parent emphasizes with the child. Rubin and Chung (2013) mention that the role of culture in parenting is significant especially in how parenting should be implemented. Although culture permeates the systems at every level of the environment, legislation should ensure that families are strengthened. The current paper focuses on examining the current frameworks and explores what is further required in South Africa to improve the parent-child relationship. These discussions are based on themes arranged on a micro-, meso-, exo- and macro- level systems at play within the lives of families in South Africa, and provides multi-level potential solutions towards improving the parent-child relationship.

\section{THE ECOLOGICAL SYSTEMS PERSPECTIVE}

Ecological Systems Theory is a developmental theory that view human development from a person-in-environment context emphasizing that all growth and development occurs within the contexts of the bi-directional relationships in and between various levels of systems. (e.g. a child must be studied in the context of the family system and the family needs to be understood within the broader community and societal culture and values). (BRONFENBRENNER, 1979). The systems within the theory include the microsystem, mesosystem, exosystem and macrosystem. The ecological perspective of Bronfenbrenner (1994) therefore provides the foundation for this article.

\section{MICRO-LEVEL SYSTEM}

The Micro Systems level-can be understood as informal systems consisting of the home, family and friends. At the micro-level the importance of developing a secure attachment between mother and child is identified, as well as the importance of a healthy mother-father relationship, the involvement of the father, nutrition and care, parenting styles including responsive parenting, and constructive discipline. Thus it refers to the intimate family system and the interactive dynamics between the household and its individuals. The following are micro-level aspects that influence the parent-child 
relationship and child development outcomes in relation to the current legislative policies in South Africa.

\subsection{Attachment}

The Integrated Parenting Framework identifies the importance of attachment between mother-and-child (DEPARTMENT OF SOCIAL DEVELOPMENT, 2012). As a healthy relationship between parent and child is regarded as the foundation for optimal childhood development and performs a natural and healthy function as the child grows. (BRETHERTON, 1992). This is manifested and clearly stated in the theoretical framework of Bowlby's Attachment Theory (1969) in which he argues that in order for a child to thrive emotionally, they require a continuous and secure caregiving relationship that provides them with the necessary environment to optimally develop. (BOWLBY, 1969). A secure attachment is developed between the child and attachment figure when the relationships they have are nurturing and has supportive mental processes which will enable a child to regulate emotions, reduce fear, adjust to others, develop empathy for others and learn appropriate moral reasoning. (ROSE; MCLNNES, 2017). On the other hand, insecure attachments may cause children to display avoidant or resistant behaviour towards their attachment figures and this negatively impacts a child's internalisation of problems, peer interaction and educational achievement at the age of five years. (BENOIT, 2004).

Previously mothers were regarded as the most pivotal parental figure in a child's life. However recently the Fatherhood Strategy identified the importance of fathers developing a secure attachment with their children as it is argued that fathers need to be responsive to their children, participate in their basic care, praise children's accomplishments and comfort them when sad. (REPUBLIC OF SOUTH AFRICA, 2013). As children with a secure relationship to both parents were found to be the most confident and competent in the study sample. (BENOIT, 2004). The Fatherhood Strategy (2013) emphasises that attachment to the father is important for the holistic growth of the child and noted several restraints in South Africa that withholds many children from such a relationship with their father. Some of the South African cultural groups hold beliefs that fathers who have children born out of wedlock are obligated to pay damages to the maternal family. This in itself, causes fathers to refrain from claiming paternity to avoid payment. (REPUBLIC OF SOUTH AFRICA, 2013). Another factor is that a poor relationship between father and mother negatively impacts the father-child relationship as contact is restricted or a relationship with the father is refused completely.

Migration to cities seeking employment further contributes to children growing up with absent fathers as many males relocate to cities in order to gain an income. (MTSHALI, 2016). This further problematizes the concept of co-parenting and involvement of fathers, which The Children's Act 38 of 2005 aims to encourage. Section 21(1) provides for biological fathers to automatically acquire 
parental rights and responsibilities if they were living with the mother in a permanent life-partnership at the time of the child's; or consents to be identified as the father; contributes to the upbringing of the child; or pays damages in terms of customary law. (REPUBLIC OF SOUTH AFRICA, 2005). Considering the law of the indigenous African people of South Africa, customary law was originally applied in the country and is still officially recognised today. (BOEZAART, 2013). Therefore, although the law provides fathers with the opportunity to be actively involved to participate in the upbringing of their children, cultural norms and traditions seem to prohibit fathers from practising their rights.

\subsection{Nutrition and care}

Part of maintaining a healthy parent-child relationship and secure optimal child development outcomes is the nutrition and care provided to the child from a very early age even before birth. This nutritional and health needs are considered as an important aspects of a child's life to ensure optimal development and these are primarily the responsibility of the parents. Recently UNICEF (2017) acknowledged that not only is breastfeeding beneficial towards the growth of the child but also fosters the development of a bond between the parent and the child. In response to this believe the Department of Health currently provides neonatal and paediatric services through community health clinics, but have not implemented programmes that encourage responsive feeding practices or the involvement of fathers. (WESTERN CAPE GOVERNMENT, 2018). The Integrated Parenting Framework (2012) recommended that the involvement of fathers need to be encouraged, but how to encourage fathers need further exploration before programmes can expand or be implemented (DEPARTMENT OF SOCIAL DEVELOPMENT, 2012). It is therefore crucial to prioritise responsive parenting in the primary health care system as well as the recognised importance of father involvement from the birth of a child.

Men's' involvement in caring routines of their children and positive relationships with the biological mother of their have been emphasised by the Fatherhood Strategy (2013) as a way of possibly decreasing the exposure to violence, abuse or developmental delays. It has been found that fathers who participated in parent-training programmes reduced domestic violence and increased their involvement in the care of their child (HETLMAN et al., 2017). Fatherhood Programmes offered through Non-Government Organisations such as Families South Africa [FAMSA], Sonke Gender Trust, Men Care as well as The Parent Centre are aimed at bringing about gender equitable parenting, encourages and highlight the importance of a father's engagement with the child. (Families South Africa [FAMSA], 2018).

Furthermore, The Fatherhood Strategy (2013) argues that the benefits of father's involvement are threefold. First, it enables fathers to get to know their children, therefore able to learn the child's personality and temperament. Second, it offers fathers exposure to caregiving, therefore 
enabling their capacities of being sensitive and responsive caregivers. Third, children consider involvement of fathers as indicators of parental love, therefore reinforcing a positive father-child relationship. (REPUBLIC OF SOUTH AFRICA, 2013). Part of maintaining a healthy parent-child relationship includes the way children are raised, responded to and reinforced by both parents. Thus it is believed that the parenting style practiced by the father and mother further impacts the developmental outcomes of their children.

\subsection{Parenting Styles}

In the year 1967, Baumrind set out the foundation for some parenting dimensions on which the integrated parenting framework (2012) elaborates on, which are authoritative, authoritarian, permissive and neglectful, respectively. Authoritative parenting style is described as a combination of three separate dimensions: involvement, warmth and inductive discipline (STEWART; BOND, 2002) whereas authoritarian parenting is a combination of high parental control, low warmth and low autonomy granting. (STEWART et al., 1999). Permissive parents are low in control, high in warmth and high in autonomy granting (UJI et al., 2014), whereas the neglectful parents are characterised by low demandingness and low responsiveness towards their children.

Baumrind's (1967) parenting styles has provided a template to measure parenting and childhood outcomes, concluding that children of authoritative parents have been found to score better in measures of adjustment, attachment, resilience, school achievement, social and school competence and prosocial behaviour than children of authoritarian or permissive parents. (ALEGRE, 2011). The Integrated Parenting Framework (2012) recommends the parental practice of the authoritative style in childrearing in South Africa. Within this framework minimal mention is made to the cultural factors at play in South African parenting, although it is advised that parents attempt to find a balance between the different parenting styles and ensure awareness to their behaviour in front of their children. The policy framework encourages parents to lead by example and agree on a parenting style to ensure a congruent parenting practice that can raise a well-adjusted child. (DEPARTMENT OF SOCIAL DEVELOPMENT, 2012).

The Integrated Parenting Framework (2012) has elaborated on the different types of parenting recorded and studied in South Africa, such as refugees families, parenting homosexual children, homosexual parenthood, children with challenging behaviour, parenting step-children, imprisoned parents, children in a struggle with the law, children abusing substances, children with disabilities, children diagnosed with HIV/Aids, grandparents parenting, single parenthood, foster parenting, adoptive parenting, divorced parenting and child-headed households (DEPARTMENT OF SOCIAL DEVELOPMENT, 2012). Although various factors that affect parenting have been elaborated 
on in the Integrated Parenting Framework (2012), much more guidance and elaborative programmes are required which appears to be lacking in the framework, and the policy fails to expand on the parenting styles and socialisation goals and factors of South African families.

\subsection{Responsive Parenting}

According to global Nurturing Care Framework participation in activities together with their children including the interaction with general household objects, talking, singing or even sharing books as it builds parental confidence and strengthens the parent-child relationship needs to be encouraged amongst parents. (WORLD HEALTH ORGANIZATION, 2018). It is one of the most important interactions that encourages personal relations, adds to the joy of living, advances childhood learning and stimulates creativity. (GLASSCOTT BURRISS; TSAO, 2002). It is unfortunate that South African legislative documents have not incorporated the importance of play within the spectrum of early childhood development and parenting.

The Children's Act 38 of 2005 , as well as the Integrated Parenting Framework tends to focus more on responsive and interactive parenting, but no direct reference is made to parents and the benefits of play on the parent-child relationship. (DEPARTMENT OF SOCIAL DEVELOPMENT, 2012; REPUBLIC OF SOUTH AFRICA, 2005). The Fatherhood Strategy is one South African legislative document that has acknowledged the importance of play, but focused this role more on fathers. Fathers have been found to have a more prominent role in enabling play exploration that carries socio-emotional developmental benefits for the child (MOORE et al., 2017). According to Louw and Louw (2007), fathers serve the role of the playful parent, but also the disciplinarian in the traditional families. Future studies should further explore the relevance of Baumrind's typologies in a South African context taking the different cultural practices into account.

\subsection{Discipline}

Parental discipline and control has been studied and theorised extensively and it has been found that social competence, academic performance, psychological development and problematic behaviour have been outcomes in children who have been found to be raised in different ways by their parents or caregivers. (DEPARTMENT OF SOCIAL DEVELOPMENT, 2012). As a parent the responsibility and exercise of discipline is an inherent aspect of in what manner and to what intensity the child will be controlled in order to develop autonomy and independence as an adult. The Integrated Parenting Framework encourages parents to find a balance amongst the different parenting styles as it leads to a well-adjusted child. (DEPARTMENT OF SOCIAL DEVELOPMENT, 2012). The Fatherhood Strategy explains that a balance in parenting style with clearly defined rules, boundaries and 
consequences are necessary for optimal child development. (REPUBLIC OF SOUTH AFRICA, 2013). Considering the South African laws, parents have a duty to ensure that discipline is administered humanely and consistent with the dignity of the child, which implies that parents have a traditional right to discipline a child that could include corporal punishment. (BOEZAART, 2013). The Integrated Parenting Framework argues that parents need to engage with different legislative frameworks that have a bearing on their children and ensure they are aware that the law is above culture when there is infringement on human rights. (DEPARTMENT OF SOCIAL DEVELOPMENT, 2012).

Positive and responsive parental discipline has become more important than ever in South Africa since the common law defence of reasonable chastisement was found to be unconstitutional as ordered in the South Gauteng High Court on 19 October 2017. (ENCA, 2017). The Bill of Rights emphasises in 28 (1) (d) that it is the right of every child to be protected from maltreatment, neglect, abuse or degradation. (REPUBLIC OF SOUTH AFRICA, 1996). Although there are no clear guidelines for parental discipline practices in the Children's Act, the Integrated Parenting Framework (2012) ensures to protect children and encourage alternative, constructive and positive parenting methods.

\section{MESO-SYSTEM}

The meso-system, is described as the interactions between two microsystems which affect the child directly, which is the schools, churches, local community and social services, thus the importance of early childhood development programmes (ECD) will be discussed below (BRONFENBRENNER, 1994).

\subsection{Early Childhood Development Programmes}

The Children's Act defines 'early childhood development' as the process of emotional, sensory, cognitive, moral, physical, spiritual, social and communication development of children from birth to school-going age. (REPUBLIC OF SOUTH AFRICA, 2005). It has been confirmed after extensive research that early childhood stimulation and education can substantially improve the developmental outcomes in later life. (UNITED NATIONS CHILDREN'S FUND, 2014). Studies related to early childhood development focus on how different factors impact physical health, mental health, nutrition, cognitive development, social and emotional development or language development. (MEIER; LEMMER; NIRON, 2017).

The involvement of fathers within the child's education has shown positive results on the child's academic progress (MOORE et al., 2017). The Fatherhood Strategy (2013) has elaborated that children score higher on verbal skill tests, problem-solving tasks and in social interactions when they have active fathers in their lives (DEPARTMENT OF SOCIAL DEVELOPMENT, 2012). The involvement 
of parents in early childhood learning unfortunately lacks emphasis in further legislation such as the Children's Act or the White Paper on Families. The Children's Act has encouraged the implementation of early childhood development programmes, but fails to acknowledge the importance of parents in their children's education before the school-going age. (REPUBLIC OF SOUTH AFRICA, 2005). It has been argued that the extensive implementation of ECD Programmes on a national level have not attempted to involve or educate parents on child development (ATMORE; VAN NIEKERK; ASHLEY-COOPER, 2012).

\section{EXO-SYSTEM}

Bronfenbrenner (1994) describes the exo-system as containing environmental elements that have a profound influence on the development of a child, although the child is not directly involved with those elements. Poverty has been identified as one such factor and thus will be discussed in relation to the impact it has on the parent-child relationship.

\subsection{Poverty}

Parenting has been identified as s possible mediators that can promote or hinder child development in poverty stricken areas. It has been argued by Gulseven and others (2018), that parents with economic restraints and who experience a depletion of resources and cause parents to become self-focused that result in less responsive parenting of their children. The lack of support systems and resources in rural areas makes the task of developing and maintaining supportive, involved parenting practices and family relationships more challenging for poor rural families. (BRODY; FLOR, 1998).

In a study by Linver, Brooks-Gunn and Kohen (2002), poverty has been found to be related to less warmth and responsiveness and more harshness in parent-child interactions, which demonstrates an association between poverty and child outcomes. Poverty has been negatively associated with good parenting in a study conducted in Malawi and South Africa, arguing that caregivers are overly occupied with providing the basic needs of the children that they lack the time and energy to maintain a positive relationship with their child (Sherr et al., 2017). The Integrated Parenting Framework (2012) identifies poverty as a contributing factor to poor parenting and exposing children to harmful environments. Men's participation as parents can be considered positive for the health and well-being of their children as children are considered more vulnerable to poverty if fathers neglect their financial responsibilities. (REPUBLIC OF SOUTH AFRICA, 2013). Three grants specifically designed to assist with the financial burden of caring for a child has been implemented by Department of Social Development; namely the Child Support Grant; Foster Care Grant and the Care Dependency Grant. According to the Integrated Parenting Framework, the three state grants are aimed at reducing poverty 
and encouraging improved care of children in harsh circumstances. (DEPARTMENT OF SOCIAL DEVELOPMENT, 2012).

\section{MACRO-SYSTEM}

The fourth system in the ecological perspective as designed by Bronfenbrenner (1994) is the macro-system, which consists of the cultural context and broader societal laws which forms the outermost layer of the child's environment. Of particular interest to this perspective are culture, power, and inter-personal relationships, group value systems, and social norms and will help us discover how the lives of individuals, families, and societies are interdependently linked. (BRONFENBRENNER, 1979). For the purpose of this article, challenging of stereotypes practised through awareness programmes will be discussed.

\subsection{Challenging stereotypes}

It has been argued that a need exists in South Africa to challenge the gender stereotyping which depict fathers as disinterested, uncaring and incapable (DEPARTMENT OF SOCIAL DEVELOPMENT, 2012) as the current health and education programmes are only targeted at mothers, which further excludes fathers from the parental role and limits access to educational services. The policy was criticised for not seriously attending to the importance of fatherly involvement and purely noting that men pose a threat to women and children if violent. (RICHTER; CHIKOVIRE; MAKUSHA, 2010). Thus the Fatherhood Strategy (2013) encourages fathers to become actively involved in the daily care of their children, which has been argued for internationally as particularly in some South African cultures care-giving is considered a women's task (HETLMAN et al., 2017).

However, the State of the World's Fathers Report (2017) prioritises the action to include all individuals to view themselves as caregivers and financial providers to children and their families, regardless of their gender. (HETLMAN et al., 2017). The report encourages the legalisation of paternity leave in order to involve fathers from birth and also provide support to new mothers. Endorsing paternity leave has produced positive results as the amendments to the Basic Conditions of Employment Act (1997) was recently open for public comment. The amendments seek to provide for parental, adoption and commissioning parental leave to employees with up to ten days paternity leaves for fathers from the day of the child's birth. (PARLIAMENTARY MONITORING GROUP, 2018). Legalising paternity leave, even if just for ten days, encourages involvement of fathers and as the Integrated Parenting Framework (2012) has argued, it will challenge stereotypes of disinterested fathers as the private sector will now encourage paternal involvement in this way. 


\section{POTENTIAL SOLUTIONS}

As discussed above it is of importance that parents are equipped with the necessary skills in order to enhance their ability of interacting with their children and have conversations with their children rather than just dictating in the parent-child relationship. Parents should also learn to understand that times have evolved, therefore the way they implement the rules and cultural expectations on their children will not be the same as how it was implemented to them by their parents. The importance of parents providing children with nutritional care and health needs should be emphasised on all levels including state agencies, and responsive parenting should be promoted.

The Children's Act has encouraged the implementation of early childhood development programmes, but fails to acknowledge the importance of parental involvement in their children's education before the school-going age. Furthermore, it is evident throughout this paper that the involvement of the father in a child's life is of utmost importance and more efficient ways needs to be found that would promote the involvement of fathers' in the lives of their children. Cultural practices therefore also need to evolve with the times and the circumstances that prevail in our societies. Given the high unemployment rate of young people in South Africa, an example of that is to allow young fathers to actively participate in the lives of their offspring, regardless whether culturally they have not met all the economic requirements towards the family of the mother of their child. It is a recommendation that further research is required to explore the relevance of Baumrind's typologies of parenting styles in a South African context taking the different cultural influences into consideration.

\section{CONCLUSION}

This paper focused on examining the current frameworks and explored what is further required in South Africa to improve the parent-child relationship. Discussions were based on themes extracted on the micro-, meso-, exo- and macro- level systems at play within the lives of families in South Africa. It was established that poverty contributed to poor parent-child relationships as it resulted in less warmth and responsiveness and more harshness in parent-child interactions, which substantiates an association between poverty and compromised child outcomes. Parenting styles were explored, and cultural aspects such as discipline and issues pertaining to poverty that affects child outcomes were highlighted. Furthermore, cultural practices around father-involvement in the lives of their children were highlighted, and multi-level potential solutions towards improving the parent-child relationship were provided. 


\section{REFERENCES}

ALEGRE, A. Parenting Styles and Children's Emotional Intelligence: what do we know? The Family Journal: Counselling and Therapy for Couples and Families,[S. I.], v. 19, n. 1, p. 56-62, 2011.

ATMORE, E.; VAN NIEKERK, L.; ASHLEY-COOPER, M. Challenges facing the early childhood development sector in South Africa. South African Journal of Childhood Education, [S. I.], v. 2, n.1, p.120-139, 2012.

BAUMRIND, D. Child-care practices anteceding three patterns of preschool behavior. Genetic Psychology Monographs, [S. I.], v. 75, p. 43-88, 1967.

BENOIT, D. Infant-parent attachment: Definition, types, antecedents, measurements and outcoume. Paediatric Child Health, [S. I.], v. 9, n. 8, p. 541-545, 2004.

BOEZAART, T. Building bridges: African customary family law and children's rights. International Journal of Private Law, [S. I.], v. 6, p.395-417, 2013.

BOWLBY, J. Attachment and Loss: attachment. New York: Basic Books, 1969. v 1.

BRETHERTON, I. The origins of attachment theory: John Bowlby and Mary Ainsworth. Developmental Psychology, [S. I.], v .28, p. 759-775, 1992.

BRODY, G. H.; FLOR, D. L. Maternal Resources, Parenting Practices, and Child Competence in Rural, Single-Parent African American Families. Child Development, [S. I.], v. 69, n. 3, p. 803-816, 1998.

BRONFENBRENNER, U. Ecological models of human development. International Encyclopedia of Education, [S. I.], v. 3, n. 2, p.1643-1647, 1994.

BRONFENBRENNER, U. The Ecology of human development: xperiments by nature and design. Cambridge: Harvard University Press,1979.

DEPARTMENT OF SOCIAL DEVELOPMENT. Integrated Parenting Framework. Pretoria: Government Press, 2012.

ENCA. It's now illegal to spank your child in SA. Johannesburg, 2017. Retrieved from: https://www.enca.com/south-africa/it-is-now-illegal-to-spank-your-child-in-sa.

FAMILIES SOUTH AFRICA. Fatherhood Project. Western Cape, 2018. Retrieved from: http://www.famsawc.org.za/fatherhood-project.

GLASSCOTT BURRISS, K.; TSAO, L. Review of Research: How Much Do We Know about the Importance of Play in Child Development? Childhood Education, [S. I.], v. 78, n. 4, p. 230-233, 2002.

GULSEVEN, Z. Et al. The mediational roles of harsh and responsive parenting in the longitudinal relations between socioeconomic status and Turkish children's emotional development. International Journal of Behavioral Development, [S. I.], p.1-11, 2018.

HETLMAN, B. Et al. State of the World's Fathers: Time for Action. Washington, D. C.: Promundo, Sonke Gender Justice, Save the Children, and MenEngage Alliance, 2017. 
LINVER, M. R.; BROOKS-GUNN, J.; KOHEN, D. E. Family processes in pathways from income to young children's development. Developmental Psychology, [S. I.], v. 38, p. 719-734, 2002.

LOUW, D.; LOUW, A. Child and Adolescent Development. Bloemfontein: ABC Printers, 2007

MEIER, C.; LEMMER, E.; NIRON, D. G. Problems and Prospects in Early Childhood Education Provisioning in Turkey and South Africa. Journal of Asian and African Studies, [S. I.], v. 52, n. 4, p. 444-457, 2017.

MOORE, T. et al. The First Thousand Days: an evidence paper. Parkville, Victoria: Centre for Community Child Health, Murdoch Children's Research Institute. 2017

MTSHALI, M. N. Role Reversal of Rural Black Grandparents in South Africa. Journal of Comparative Family Studies, [S. I.], v. 47, n. 3, p. 369-377, 2016.

PARLIAMENTARY MONITORING GROUP. Labour Laws Amendment Bill [B29-2017]. [S. I.], 2018. Retrieved from: https://pmg.org.za/call-for comment/677/?utm_campaign=request-for-comment-from parliament\&utm_source=transactional\&utm_medium=email.

REPUBLIC OF SOUTH AFRICA. Department of Social Development. Fatherhood Strategy. Pretoria, 2013.

REPUBLIC OF SOUTH AFRICA. Government Gazette. Children's Act. 38 of 2005 (No.28944). Pretoria, 2005. Retrieved from:

http://www.hpcsa.co.za/Uploads/editor/UserFiles/downloads/legislations/acts/childrens_act_38_2005.pd f.

REPUBLIC OF SOUTH AFRICA. The Constitution of the Republic of South Africa. Pretoria: Government Press,1996

RICHTER, L.; CHIKOVIRE, J.; MAKUSHA, T. The status of fatherhood and fathering in South Africa. Child Education, [S. I.], v. 86, n. 6, p. 360-365, 2010.

ROSE, J.; MCINNES, K. Attachment and parental sensitivity: their role in supporting good child development and lifelong outcomes. England: How Action for Children Works, 2017.

RUBIN, K. H.; CHUNG, O. B. Parenting beliefs, behaviors, and parent-child relations: a crosscultural perspective. New York: Psychology Press, 2013.

SHERR, L. Et al. Parenting, the other oldest profession in the world - a cross-sectional study of parenting and child outcomes in South Africa and Malawi. Health Psychology and Behavioral Medicine, [S. I.], v. 5, n. 1, p. 145-165, 2017.

STEWART, S. M. et al. Functional Parenting in Pakistan. International Journal of Behavioural Development, [S. I.], v. 23, n. 3, p. 747-770, 1999.

STEWART, S. M.; BOND, M. H. A critical look at parenting research from the mainstream: problems uncovered while adapting Western research to non-Western cultures. British Journal of

Developmental Psychology, p. 379-392, 2002. 
UJI, M. et al. The Impact of Authoritative, Authoritarian, and Permissive Parenting Styles on Children's Later Mental Health in Japan: Focusing on Parent and Child Gender. Journal of Child and Family Studies, [S. I.], v. 23, p. 293-302, 2014.

UNITED NATIONS CHILDREN'S FUND. Building Better Brains: New Frontiers in Early Childhood Development. New York, 2014

UNITED NATIONS CHILDREN'S FUND. Early Moments Matter for Every Child. New York, 2017.

WESTERN CAPE GOVERNMENT. Departments of Paediatrics and Child Health: Overview. Neonatal Services. Better Together, 2018. Retrieved from: https://www.westerncape.gov.za/your_gov/176.

WORLD HEALTH ORGANIZATION. Nurturing Care for Early Childhood Development. Geneva, 2018. 